\title{
Medical device risk management and its economic impact
}

\author{
Katerina Krsteva Jakimovska ${ }^{1 *}$, Marija Glavas-Dodov², Jasmina Tonic-Ribarska², \\ Suzana Trajkovic-Jolevska \\ ${ }^{1}$ Promedika DOOEL, Skopje, Macedonia \\ ${ }^{2}$ Faculty of Pharmacy, University Ss. Cyril and Methodius in Skopje, Macedonia
}

Received: September 2013; Accepted: October 2013

\begin{abstract}
The importance of medical devices in everyday users/patients lives is imensse. This is the reason why emphasis must be put on safety during their use. Satisfactory safety level can be achived by implementation of quality and risk management standards. Medical device manufacturers must learn to deal with the potential risks by using theoretical and practical examples and measures in order to protect their users/patients and themselves from suffering huge losses arising from adverse events or recall of their products. The best moment for implementation of risk management methods and analysis begins from the device design and development through manufacturing, sales and distribution. These way medical device manufacturers will succseed in protecting their users/patients from serious adverse events and at the same time protect their brand and society status, while minimizing economic losses.
\end{abstract}

Key words: medical device, risk management, adverse events, medical device market, risk-benefit.

\section{Introduction}

Medical devices are vital and integral part of the healthcare system. They have an enormous impact on everyday life quality of all users/patients. Because of this, their safety, quality and efficacy must be assured.

Medical device safety can be viewed by using relative terms. All devices carry certain risk level and during certain circumstances can cause a problem/adverse event. Most of the problems that appear cannot be detected until the medical device is placed on the market and actually used by a patient/user. For example, an implant can show a problem that was not predicted at the moment of implantation. The problem can represent a state that appears only in certain special patients. Some medical devices can experience problem with its consisting components. Yet, some of the problems that appear can be detected so early, for example, during the design phase. Because of this, it is

\footnotetext{
* krsteva_k@promedika.com.mk
}

recommended that risk management processes are applied during the entire life-cycle of the medical device.

\section{Risk and medical device risk management}

The term risk, as defined in WebFinance Bussiness dictionary (Webfinance, 2014), represents a probability or a threat by a hazard, loss or other negative occurrence triggered by external or internal vulnerabilities that can be neutralized by forward taken activities.

The medical device safety approach is consisted of; assessing the potential of the medical device to cause a hazard resulting in safety problems and danger to the patient/user. This is referred to the term risk assessment.

By other means, the term hazard represents the potential for a medical device to show certain adverse event or to represent a source of danger. The term risk refers to a measure for the combination of hazard, the possibility for occurrence of adverse event and the seriousness of the entire event. 
Medical devices cause hazard only if there is sequenced occurrence of events that result in hazard situation. The event sequence may include one event or a combination of events. Hazard situation appears when users/patients or the environment are exposed to hazard. But it must be underlined that a hazard situation may appear even when no visible mistakes exist. In cases when hazard situations occur because of a mistake, the probability of the mistake is not the same as the probability of a hazard occurrence. Mistakes may not always result in hazard situations, and the hazard situations may not always result in hazard.

The risk management goal is to maximize the benefit of the medical device use and minimize the risk occurrence during their use.

In everyday practice, medical device manufacturers have to strive for obliged incorporation and proper use of the Quality Management System (QMS) and Risk Management System (RMS). This is to be done for one and only reason and that is insuring safer products for the patients/users. During the last few years we are witnessing more and more medical device recalls. This is the reason why authorities strive for more demanding requests on incorporation of these standards in the processes of development, design, manufacturing, distribution (the whole life cycle of the medical device). These two systems can exist on their own, but they can be incorporated one into another and this way they would reduce expenses and improve efficacy.

The international standard ISO 13485:2012 represents a system that specifies the requirements on the quality management where the organization demonstrates its ability to assure medical devices that encounter both the regulatory and customer needs. Effective QMS is essential for assuring safety and good performance of the medical devices. Good defined QMS includes safety issues on different specific areas. Knowing the importance of device safety is useful to identify some safety activities that specially imply on safety issues and assure proper input and fitback from the unique activities to QMS.

The degree that the safety issues are analyzed should be adequate to the degree of the risk and the nature of the medical device. Some of the medical devices have low risks or well known risks, and eventually some of the devices represent the state of the art and their risks are still not known and are about to be discovered.

The risk management principles should apply during the entire medical device life-cycle and they should be used identifying and addressing the safety issues. Risk management represents an important part of effective system for assuring quality and safety, and the reason for this is that decision making should be documented on the risk basis. The risk is usually evaluated in two perspectives: safety risks and business risks.

ISO 14971:2007 represents a second edition and it substitutes the edition issued in year 2000 ISO 14971:2000. At the same time it substitudes Annex 1 from this edition
(ISO 14971:2000/Amd 1:2003). The second edition was issued in 2007, and in 2012 was issued ISO 14971:2012 that serves as updated 2007 edition.

This international standard provides system where the experience, clear point of view and judgement are applied systematically in order to manage the risks related to medical device use. This system was specially developed for medical device manufacturers that use principles based on risk management. For all other participants for example, the ones from the health industry, this standard can be used as informative guidance in the development and maintenance of the system and the risk management processes. This standard manages the risk management processes primarily to patient/user, but also to the operator, other equipment and the environment.

Generally, in all activities where the organization or the individual are included they can expose themselves or the other stakeholders to hazard that can cause a loss or harm of their values. Risk management is a complex matter because every stakeholder sets different value on the opportunity to the harm occurring and its seriousness.

All stakeholders, must understand, that medical device use involves certain degree of risk. Risk acceptability depents on various components important for the stakeholder. To make a decision for a medical device to be used in certain clinical procedure needs all residual risks to be balanced against expected benefits. These decisions can be made only by qualified medical personal that has abundant knowledge of the patient's health or the patient himself.

As part of all stakeholders, the manufacturer makes decisions about the medial device safety, including the risk acceptability. The only goal of these complex decisions is to put a safe medical device on the market, with a proper use. ISO 14971 has specific procees that provide every manyfacturer with techniques to identify all hazards related to the medical device. These processes also help to asses and evaluate the risks related to these hazards, to control and monitor the effectiveness of these hazards. The requirements from this standard have their own application in every stage of the medical device life cycle.

The risk management is defined as the probability for the harm to arise and the concequences from this harm, or how dangerous can it be. The manufacturer must consider this definition and than apply the processes of:

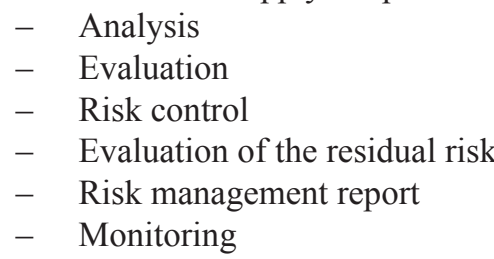

In this way manufacturers identify the possible hazards and hazard situations and demonstrate that the exsisting risk is minimized and brought to an exceptable level.

Once the characteristics of the medical device are identified, the risk assessment process can begin. At first

Maced. pharm. bull., $59(1,2) 49$ - 60 (2013) 
Table 1. Medical device global sales per year (in billion dollars)*

\begin{tabular}{lccccc}
\hline \hline Region & 2009 & 2010 & 2011 & 2012 & 2013 \\
\hline America & 102.4 & 107.1 & 112.1 & 117.4 & 122.8 \\
Western Europe & 62.3 & 66.7 & 71.6 & 76.9 & 82.5 \\
Asia/Pacific & 42.5 & 46.1 & 49.9 & 54.3 & 58.9 \\
Central/Eastern Europe & 10.3 & 11.3 & 12.4 & 13.6 & 14.8 \\
Africa/Middle East & 5.7 & 6.0 & 6.3 & 6.7 & 7.0 \\
Total & 223.2 & 237.2 & 252.3 & 268.9 & 286.0 \\
\hline
\end{tabular}

*Source: Medical Market Fact Book, 2008

hazard identification is made and then evaluation and other actions are taken to make the risks acceptable. All action taken need to be re-evaluated to assure that the risk is minimized to a certain level and no additional risks are created (Dumbrique, 2010).

From above can be concluded that ISO 14971 standard provides manufacturers with risk management frame procedures that are related to the medical device usage. This way the manufacturer can easily identify, asses, evaluate and control the risks and monitor its effectiveness.

\section{Medical device market}

The main reason for medical device growth (both manufacturing and sales) is the incrised requirements and needs by the population that reaches its 50 and 60 (so called baby boomers). This population wants to maintain its vitality as long as possible. So, manufacturers continue to research new ways for growth, development and satisfaction of the needs pointed by the potential buyers.

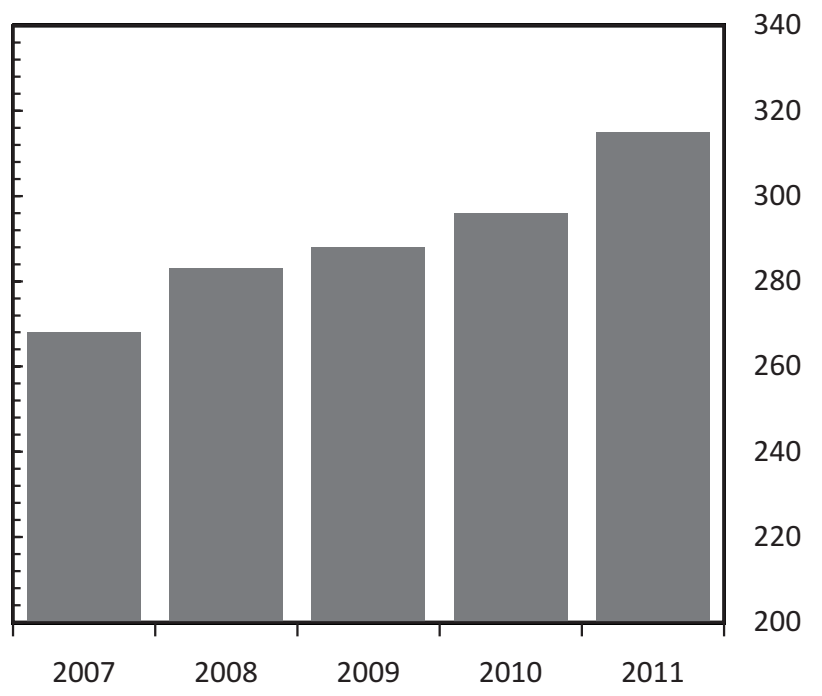

Fig. 1. Medical device market revenue history (USD) (adapted from http://www.slideshare.net/ FrostandSullivan/european-medical-devicesindustry-assessment-a-symptomatic-evaluation).
The Gross Domestic Product (GDP) in Europe is aproximatly 1 trilion euros. Every year, $8.7 \%$ of the European GDP are spent for health care, and $6.3 \%$ (63 bilion euros) from this amount are spent on medical devices that derive from the European market. This represents 0.5$0.6 \%$ from the entire European GDP. Medical devices global sales are shown on Table 1.

According to the Frost and Sulivan report (Praveen, S.M., 2012), which demonstrates hronological review of the world medical device market (Fig. 1), conclusion can be easily reached. It can be seen the continous growth of the rewenues that companies made in this field.

As it can be seen, in 2013 global sales of medical devices is expected to be 286 billion dollars. Approximatelly 123 billion dollars originate from USA market, approximately 100 billion dollars originate from European market (western European and central/eastern European), while 60 billion dollars from the Asia/Pacific (Japanise) market.

In the near future it is expected that the medical device market will continue to grow above average. It is expected that by 2015 the medical device market will have annual growth of 7\% (Reportlinker, 2014). However, the USA medical device market remains to be the lider with greater volume, and the reason for this is the presence of the innovation and foreward technology. The main driving force for this above average growth is the increased number of the population in the development countries that reaches deep ages and the strong position for export of the medical devices in the European industry. USA, Europe, Japan and Canada markets are exteremely big markets, but at the same time they are ripe markets that have stable and relatively low yearly growth rate of the demand and compsumption of medical devices. This is the reason why medical device manufacturers have to seek new alternative markets to ensure its further growth. So, in the near future out of great importance will be the export of the medical devices in the fast growing and over populated countries like China and India, where cheap work force is available (Zimmermann, 2008). 


\section{Adverse event trend and medical device recalls}

Reacently, more and more patients/users experience adverse events that arise from the medical device use. Investigations are made for better understanding the reasons for the gaps in quality and safety. These investigations reveal exsistence of systematic gaps in the manufacturer and industry quality approach.

In the last 10 to 20 years, medical device industry enjoys great growth both in revenues and technology complexity. It was noted that serious adverse event reports associated with the use of medical devices exceeds the growth of $8 \%$ per annum calculated from 2001 until today. Thereby provided 'root cause' analysis reveals that failures in the product design and production process control itself constitute the main reason for more than half market withdrawals. Results have not met the common thought that the main reason for product withdrawal is found in the therapeutic area range.

Between 2001 and 2009, reported side effects have increased approximatelly $15 \%$ per year, i.e. from 57,000 report adverse effects in 2001 to more than 207,000 reported side effects in 2009. From 2005 to 2009 the rate of reported side effects has significantly risen to $19 \%$ annually. The emerge of serious side effects with the obtained resultsdeath, life-threatening, disability or hospitalization rose $17 \%$, from 8000 in 2002 to 28,000 in 2009. During this period the USA medical devices market profit doubled in size. Although the extent of this growth and the occurrence of adverse events are controlled, adverse event reports grew at a rate of $8 \%$ per year, with a sharp increase of $14 \%$ per year starting from 2005 till 2009.

Several factors contribute to the growth of the adverse events. These factors include increased requirements for reporting adverse events which are given on the recommendation of the FDA, which is accompanied by increased sensitivity of producers to these requirements. Part of this growth is a result of the growth in the number of medical devices that are used.

Growth of the number of recalls increases at a lower rate than the growth in the number of adverse events, but also it is determined that their growth is in line with the growing industry of medical devices. In 2003540 recalls were registered, and by 2009 this number increased to 763 , at an annual rate of $6 \%$. Divided by classes, Class 2 medical take up to $80 \%$, followed by Class 3 devices taking around $15 \%$ of recalls.

The increased growth of the adverse events carried out by the devices is attributed to the medical devices that are responsible for life sustaining, but the same it does not refer to the increased number of recalls. In 2003, 27\% of the adverse events accounted for Class III medical devices, by 2009 this figure increased to $40 \%$. Consequently, class III medical device recalls are reduced from $17 \%$ of total withdrawal in 2003 , to $7 \%$ in 2009 . The decreased number of medical device recalls in class III devices is a direct result from implementation of the risk management proceses by the manufacturers of medical devices.

The risk of adverse events is not uniformly distributed within the industry of medical devices. Certain therapeutic areas show a larger share of appearance of adverse events. The research adopted the conclusion that the medical devices in the areas: cardiovascular, IVD, surgical instruments (in comparison with 13 other therapeutic areas) make usp the largest number of reported adverse events. These three therapeutic areas make up the majority of total reported adverse events - and that share is $6 \%$.

With systematic root causes analysis of the medical device quality, it has been established that there are 36 main reasons for beginning a recall procedure. The reason for recall can be found in the area of design, supply, manufacturing, production and change, and the cause for the recall might be the hardware, software, labelling, packaging, procees or regulation. During this surway it was determined that almost one third of total recall $(\mathrm{N}=4391)$ was due to errors in the design area (around 31\% of all recalls), and the remaining quarter is a result of problems in the manufacturing process (around $24 \%$ of all recalls). As a surprise was the fact that only $12 \%$ of all recalls was in the postproduction area (FDA, 2011).

\section{Quality economy}

It must be emphasized that the quality economy changes through the years. In the past, when the products were placed on the market in the early stages of development, it meant that the use of the medical device in its early stages is much more cost approved, than the costs ocurred as a result of a high level of quality and reliability absence. But this is no longer the case and there are three major reasons for that:

- Increase of the risk for failure deriving from the product quality - the increased complexity of medical devices and the complexity of the user environment, simultaneously increased the likelihood of significant adverse events in terms of quality

- Increasing costs as a result of failure in the quality - costs resulting from adverse events in the field of quality in medical devices have increased as a result of increased attention by regulatory, legal bodies and the media. Fig. 2 shows the average drop in the share price of companies which can be seen to be quite significant and increased in the last decade. Fig. 3 shows a few recent examples of events in the area of quality that quite raised the costs (exspences) for the manufacturers.

- Increased transparency and its conversion into quality- Trend leading to research on the comparative effectiveness of medical devices will provide increased visibility of their quality 
and performance. Comparisons of therapeutic opportunities in medical devices will raise the quality and safety of specific medical devices. The formation of databases that would gather data on adverse effects through public-private collaboration is expected to lead into increased alertness and awareness of adverse effects and defects in medical devices.

\section{Overcomming risks by using experience analysis}

Medical device manufacturers are faced daily with enormous risks deriving from regulatory, legal and financial nature. It was determined that risks result from the manufacturers' production line and operational processes that were used in the manufacturing process. Risks may have a wide range. They may represent small disturbances in the operational functions, up to loss of consumer trust and the brand confidence.

It was concluded that companies that enjoy growth in profits and turnover, understand that their success is conceived on the base of things that their customers appreciate, such as:

- Product quality and innovation,

- Brand and reputation,

- User support and

- Flexibility.

These types of companies have more formal processes that foster teamwork between departments and colleagues.

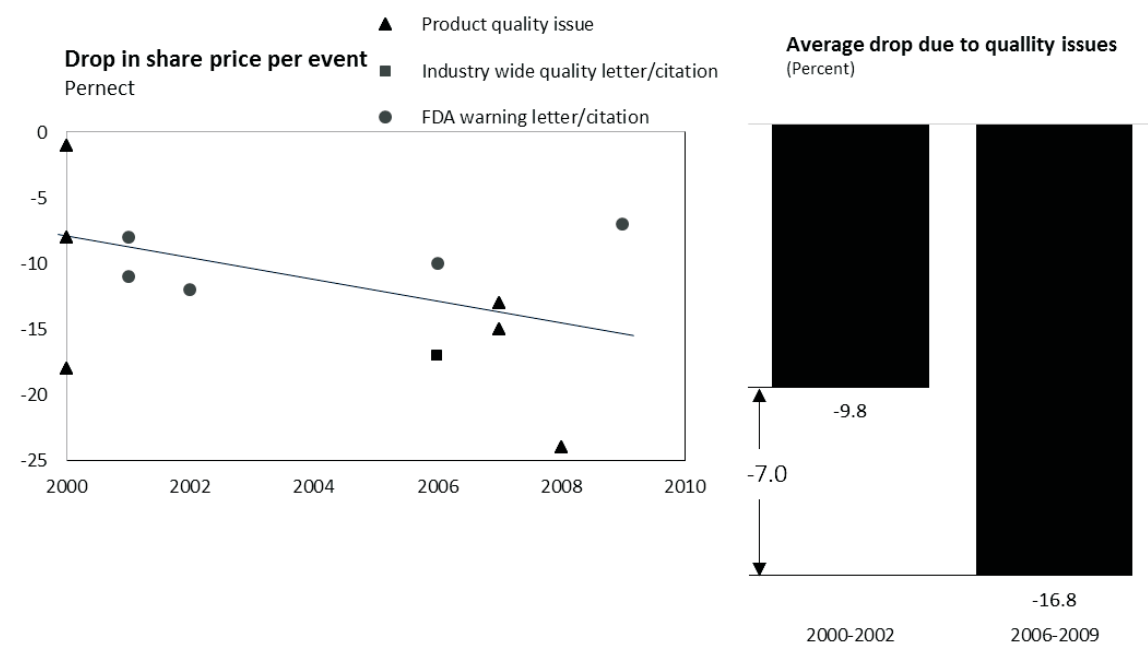

Fig. 2. Size and trends in medical device company share price drops following specific major quality events (FDA, 2011).

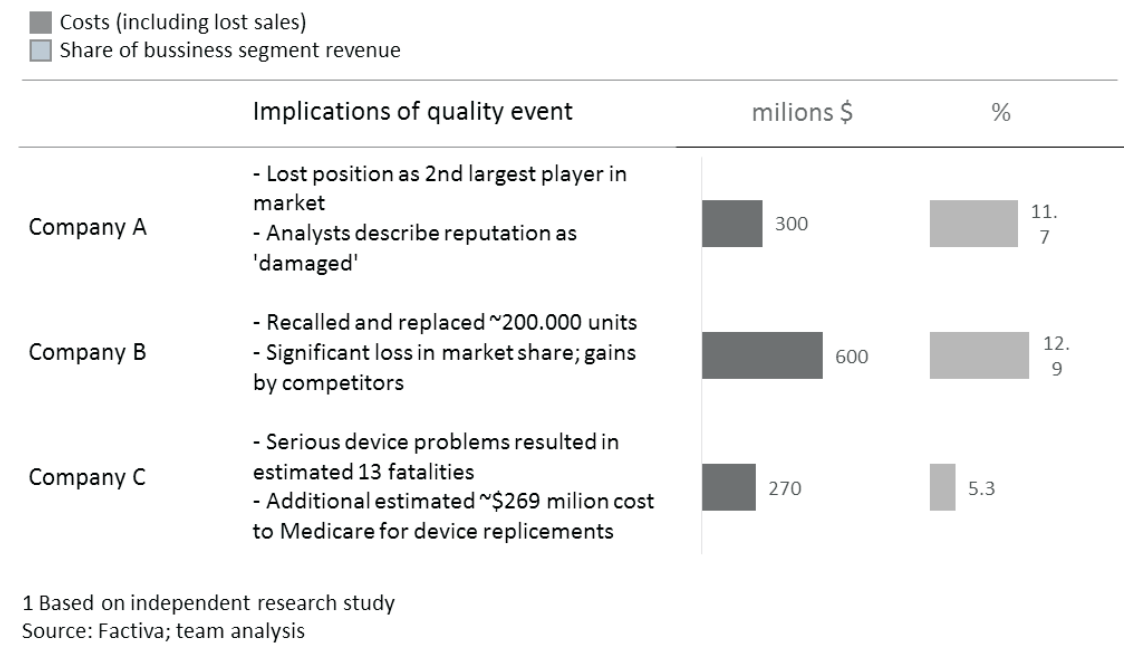

Fig. 3. Examples about the financial impact on the selected quality event incidents. 
That way they can easily overcome potential risks.

The survey (http://www.ptc.com, 2008) found out that although nearly all companies are focused on risk management processes and analysis, implemented processes and practices may be incomplete. Some of the weaknesses of risk management processes include poorly managed product development, poor cooperation between sectors, incomplete risk analysis, incomplete or lack of root cause analysis, inconsistent information and manually processed documents. From here it becomes clear how risks are created for users/patients and business success.

Risk management can take many forms. The most obvious view of the risk management process includes risk for patients who use the medical device and from this point of view the risk to the business. Theoreticaly the risk management process ensures patient safety and it is supposed to reduce the overall risk and contribute to a greater likelihood of profit.

Many of the medical device manufacturers made clear that the processes used to meet regulatory requirements and validation cause constraints in the business. In fact many of the manufacturers feel pressured by regulatory bodies. Manufacturers stated that they constantly needed to teach the latest technologies and regulatory bodies have the impression that they constantly play the role of police. Working under pressure leads to more opportunities for oversight.

The biggest challenge for the large number of manufacturers is the ability to see the overall picture of the company and linking factors through products, departments and premises to the actual risks and thus effectively overcoming the risks for patients and business. Manufacturers describe some strengths and weaknesses in their approaches to risk management (Table 2).

It is also believed that the competitiveness and volume growth represent areas that can contribute to occurrence of potentially increased levels of risk. Adopting new technologies and innovation can also represent a source of risk. However, it must be noted that risks lead to increased profits, but also can lead to a huge loss if not controlled, especially in the early stages of design and development.
The question is where the manufacturer of medical device should invest in order to overcome the risks. On one side, it is believed that special attention should be paid to research and development approaches focused on innovation, and on the other hand attention should be paid to the risk management and all the necessary analysis, as well. Also it is agreed that the timely planning, design and similar efforts contribute to reducing the risk, rather than actions taken when a problem arises.

So, it can be concluded that out of enormous importance is the cooperation and information flow between departments within the companies. Lack of cooperation can lead to increased overall risk. Most of the companies store the informations and data in paper form, eventhough they believe that these data are difficult to obtain. The data can be inaccurate and its reassessment can only slow down the overall process. For this reason most helpful is the implementation of software systems as a program resource planning, electronic document management system, supply chain management system, supplier relationship management. In order to fully use the software companies need to integrate applications that provide data stream. As they experience greater growth and complexity of the products, the explosion of information management will be more difficult without the use of appropriate software.

Medical device manufacturers have a huge opportunity for growth and profit. But this growth contributes to increasing complexity and risk. It can be concluded that risk management is a critical issue for manufacturers of medical devices. Manufacturers increasingly understand that reducing the risk to patients, assists in reducing the business risk (FDA, 2011).

\section{Risk-benefit analysis}

The risk-benefit analysis is not necessary to be performed by the manufacturer for each and every risk. This analysis is used to justify a particular risk in case when all practical risk reduction measures were applied. If the risk has not been judged as acceptable after the application of these measures, it is necessary to obtain risk-benefit

Table 2. Areas of strengths and weaknesess amnog manufacturers of medical devices

\begin{tabular}{ll}
\hline \hline \multicolumn{1}{c}{ Strenghts } & \multicolumn{1}{c}{ Weeknesses } \\
\hline $\begin{array}{l}\text { Consistent and aligned risk-based analysis for all areas with } \\
\text { lifecycle approach }\end{array}$ & $\begin{array}{l}\text { Isolated departments working with piecemeal software that does } \\
\text { not foster teamwork } \\
\text { Constantly improving standards }\end{array}$ \\
$\begin{array}{l}\text { Cound process\&mindset at early concept phase to stop or push sigma } \\
\text { projects by analysis }\end{array}$ & $\begin{array}{l}\text { Postmarket surveillance does not feed prevention at concept stage } \\
\text { Root cause analysis\&trending for re-occurence }\end{array}$ \\
$\begin{array}{l}\text { sit on standards committeesto stay in front of practices } \\
\text { Clinician staff \& QMS software for complaints }\end{array}$ & \begin{tabular}{l} 
Regulatory affairs views all change as risk \\
\hline
\end{tabular}
\end{tabular}


analysis in order to determine whether a medical device will provide more benefit than harm.

Generally, if all practical control measures are insufficient to meet the criteria for acceptability of risk in the risk management plan, the design of the medical devices needs to be abandoned. But, in some cases the major risks can be justified if they exceed the expected benefits from the use of the device. The decision whether the risks outweigh the use is essential work decision by experienced individuals with greater knowledge. Further risk reduction is necessary to take into account before evaluating the benefits. Unfortunately, there is no standardized approach for assessing benefits, and it should be done usin case by case approach.

\section{Benefits Assessments}

The benefits of the medical device use are related to the probability of emergence and continuous improvement of health which is expected. The benefits can be estimated from the following:

- The performance expected during clinical use

- Expected result from the clinical performance

- Factors that are out of importance to the risks and benefits from other possible treatments

The assessment of usefulness is heavily dependent on the reliability of the evidence relating to these factors.

This includes recognizing the possibility of the existence of possible outcomes and factors, as listed below, which is necessary to take into account:

- It is difficult to compare different results, such as what is worse, the pain or the loss of mobility? From the side effects you can get different results which can greatly differ from the initial problem.

- It also involves not stable outcomes. They may arise from the time it takes for recovery and long-term effects.

Due to difficulty of having a rigorous approach, it is generally acquired compsumptions to be simplified. For this reason, most effective way is to put focus on the most common results for each option.

Assessment of the clinical benefit may vary at different stages of the design cycle of a medical device. If available clinical data show constant performance and effectiveness of the product, the clinical benefit can be estimated. In cases where clinical data are with limited quality and quantity, benefits are estimated with greater uncertainty.

For example, sometimes it is necessary to estimate the expected level of health improvement in early stages, but in apsense of relevant clinical data likelihood of achieving the required performance and the desired clinical effect will have to be provided by reference measures for ensuring quality as well as in vitro and in vivo performance characteristics.

Where significant risks are present and there is a high degree of uncertainty in the assessment of the benefits, the expected performance or efficiency may soon be confirmed by surrogate study or clinical trial.

All of this is necessary to determine that the riskbenefit balance is as expected and prevents unwanted exposure of patients to a residual risk.

\section{Criteria for assessing the risk-benefit}

Those who are involved in risk-benefit decision making have a responsibility to understand and take into account the technical, clinical, regulatory, economic, social and political influences that relate to their decisions. This may include interpretation of the requirements set out in regulations and standards applicable to the product under expected conditions of use. Since this type of analysis is highly product-specific, a general guide for further use is impossible. Instead, the safety requirements specified by the standards relating to specific products or risks are considered to be coexistent with a certain acceptable level of risk. It should be noted that sometimes clinical trials, in accordance with the legally recognized procedures, could be required, in order to verify that the balance between medical benefit and residual risk is acceptable.

\section{Risk-benefit comparision}

Direct comparison of risks and benefits is valid only if a common scale for comparison is used. When using this type of comparative scale for risk-benefits, quantitative evaluation can be made. Indirect risk-benefit comparison does not use a general scale and and is not evaluated qualitatively. Whether qualitative or quantitative comparisons are made, it is necessary to take into account the following facts:

- Initial literature survey for potential hazard class of the product can provide significant insight into the risk-benefit.

- Medical devices with high risk-high benefit ratio usually represent the best access technology that provides medical benefits, but does not eliminate completely the risk of injury or illness. For this reason, understanding the current technology that relates to medical practice is required to perform an accurate riskbenefit analysis.

- In order to perform validation for acceptable risk-benefit criteria, it is necessary to perform clinical testing. Clinical testing can quantify the use and risks. Also, through clinical trials 
the acceptability to the society (patients, consumers and medical staff) can be examined.

- Labels for devices with high risk-high benefit should contain relevant information for users, patients and medical staff in order to provide risk-benefit to individuals immediately prior to use of the device

- Medical devices with high risk-high benefit have additional regulatory requirements that need to be met before being placed on the market

- Prior to launch a new or revised product that required a risk-benefit analysis, the manufacturer should summarize the available information related to the determination of risk-benefit and to document these findings.

As a summary, if the residual risk is found to be unacceptable using the criteria set out in the risk management plan and if further risk control measures are not applicable, the manufacturer has to collect and review data and literature to determine whether the medical device use overweights the remaining risks. If these data do not support the conclusion that the medical device use overweight residual risks, the risk remains unacceptable. For the risks that is demonstrated that overcome the benefits of use, the manufacturer has to decide which security information is necessary to be given for the purpose of revealing the residual risk.

\section{Duty to warn (labeling)}

Duty to warn applies to all reasonably foreseeable risks of use and abuse of the medical device, the method of storage, storage/cleaning and disposal of the product. Liability arises if warning marks are unsuccessful or inadequate.

Warning labeling covers specific risks and provides instructions that describe how to avoid risks or how to facilitate other ways to overcome the risk. The purpose of the warning is to inform the user how to behave in a way to avoid injury.

Adequate warning (position labeling/leaflet, specificity of risk, intensity language) should be noticeable, understood and with the appropriate intensity level. Detectable designations are very important because the product can be properly designed and manufactured, but will pose a risk in the absence of warning or absence of proper risk communication.

The duty to warn can be defined as: a reasonable person would want to be warned.

The manufacturer has an obligation for post-sale duty to warn because some hidden risks become apparent after the distribution and market sale. Post-sale duty to warn includes a duty to monitor the changes in technology complaints and post production risks monitoring.

It is generally accepted that the manufacturer knows

Table 3. Review to the manufacturers quality and values*

\begin{tabular}{|c|c|c|c|}
\hline \multirow{2}{*}{ Value stream steps } & \multicolumn{3}{|c|}{ Quality } \\
\hline & Operating system & Management infrastructure & Mindset \& behaviours \\
\hline $\begin{array}{l}\text { Product/process } \\
\text { design }\end{array}$ & $\begin{array}{l}\text { "The way value streams and } \\
\text { resouces are configured and } \\
\text { optimized for safe and timely } \\
\text { delivery of customer demand at } \\
\text { lowest lifecycle cost" }\end{array}$ & $\begin{array}{l}\text { "The formal structure processes, } \\
\text { and systems through which the } \\
\text { operating system is managed to } \\
\text { deliver the business objectives" }\end{array}$ & $\begin{array}{l}\text { "The way people think, feel, } \\
\text { and conduct themselves in the } \\
\text { workplace, both individually } \\
\text { and collectively" }\end{array}$ \\
\hline Supplier management & $\begin{array}{l}\text { - Continuous flow of materal and } \\
\text { information throughout value stream } \\
\text { - Institution of standard operating } \\
\text { procedures for each process stop } \\
\text { focusing on value-added } \\
\text { - Scheduling of capacity to meet } \\
\text { demand }\end{array}$ & $\begin{array}{l}\text { - Performance management } \\
\text { including Key Performance } \\
\text { Indicators (KPIs), metrics, target } \\
\text { setting, reporting, and monitoring } \\
\text { - Talent management/HR including } \\
\text { clear roles, responsibilities, and } \\
\text { accountabilities }\end{array}$ & $\begin{array}{l}\text { - Leadership alignment and role- } \\
\text { modeling } \\
\text { - Clear direction and compelling } \\
\text { purpose } \\
\text {-Discipline, collaboration, and } \\
\text { trust }\end{array}$ \\
\hline Manufacturing & $\begin{array}{l}\text { - Focus is on eliminating waste, } \\
\text { variability, and inflexibility }\end{array}$ & $\begin{array}{l}\text { - Organization design (e.g. aligning } \\
\text { the organization with the value } \\
\text { stream) }\end{array}$ & $\begin{array}{l}\text { - Conformance to internal } \\
\text { quality guidelines (e.g. SOPs) }\end{array}$ \\
\hline $\begin{array}{l}\text { Post-production } \\
\text { activities }\end{array}$ & $\begin{array}{l}\text { - Implementating learnings from } \\
\text { market feedback }\end{array}$ & - Monitoring market feedback & $\begin{array}{l}\text { - Continuous-improvement and } \\
\text { quality mindset }\end{array}$ \\
\hline
\end{tabular}

*adapted from http://www.ptc.com/WCMS/files/141876/en/RiskManagementMedDevStudyReporFinal.pdf 
or should have known the potential or existing risks, but sometitemes there is not need to warn if the danger was obvious or generally known by the general public.

\section{Opportunities and recommendations for improving the quality within the industry of medical devices}

Within the medical device industry there are several areas that have potential to improve quality assurance and risk reduction. These steps in the system of values are divided into three domains operating system, infrastructure and management thinking and behavior.

Operating systems include the ways for configurating product performance and optimize systems in an efficient manner. Infrastructure refers to the formal management structures, processes and systems through which operating system is mannaged to achieve the business goals. The way of thinking and behavior, describe how the employees think, feel and behave on their jobs (Table 3).

There are several best practises that can be used by the manufacturers in order appropriately to design and validate the requests for the medical device use. Some companies use formal statistcs tools for translating the user requests in excact technical specifications. Other companies use discusions, advises, expert recommendations and leading clinical experts to achieve the same goal.

Many manufacturers use software programs that do not follow the latest trends, while these programs are used by different users in different applications and environments. Software manufacturers often use inheritance which in some parts is inadequate. The recommendation to manufacturers would be that it is more effective to deal with the design and validation of the software system.

Manufacturers that have mechanisms for monitoring and feedback of the use of medical devices after they are put on the market, are more able to define critical performance parameters in the design of a device that supports the processes and controls of the supplier. Mechanisms also serve as the basis of continuously refining the estimates for the baseline risk assessment of medical devices. Manufacturers can use predictive analysis to build a model to predict the performance of medical devices that will be used prior to its production and marketing, which would additionally be refined on the basis on the actual performance of the medical device.

Companies that manage well their suppliers use several good practices. They carefully select and contact suppliers, with involvement of the internal quality of the organization. That is the way to identify vendors who work with the most critical aspect of their products. These vendors invest in the training of the perssonel and monitoring of the devices. Medical devices companies managing with their suppliers this way are able to stop the cooperation with the suppliers if the quality of the performance decreases.

Manufacturers that have defined quality measures related to medical device design phase, enjoy many benefits. Quality is measured during the design phase, enabling manufacturers to focus their resources on the most critical elements in the value chain especially in the supply quality management. Others indicated that the percaution measures were a key factor in directing effective thoughts to quality in the organization.

Some manufacturers have separated instead of integrating the quality features. So, as a recommendation to the manufacturers would be anyone who is involved in the value chain of the production quality to be obliged to accept ownership.

Integration of a strong culture of quality within the organization is a recommendation for all the manufacurers. All employees need to be bound to respect and promote the quality culture.

\section{Usefull practices and learned lessons as advice for successful medical device risk management}

All described obligations that manufacturer has to carry out during manufacture, distribution and sale of medical devices. Show that risk management is a huge area that must be carefully implemented. Manufacturers can use some of the following practices in the everyday production in order to protect themselves and still manage the risk successfully.

\section{Learning form the contractual and already closed trials}

Practice proved that companies that are divided into sectors and departments, have bad communication between production and quality assurance and very rarely mutually exchange information. In order to oppose this practice it was given an interesting idea; performing the 'root cause' analysis. The root cause analisis presents a thechique of reconstruction of the event that happened, a kind of "autopsy".

Common causes of defects in products, problems or complaints include:

- Giving preference to the finances before the quality of the product (overlooking hidden costs or poor quality)

- Giving priority to scheduled considerations insted to quality considerations

- Raising the level of political considerations over quality matters (internal policies and external marketing)

The purpose of this practice is to learn from past events. It is known from experience that companies often invest in the risk management when serious event occured. But, this should not be the practice if the manufacturers want to protect themselves from unforeseen risks and legal 
proceedings. Therefore, manufacturers should carry out a risk assessment early in the phase of development and design of the product itself) and that obligation must never evade (Quinley, 2007).

Compliance with regulatory requirements as a beginning of the risk management processs - but not as highest level of achievement

Compliance with the regulatory requirements is necessary and obligatory, but not sufficient for good risk management. Companies that have outsourced activities must have strong program compliance in order to protect themselves from fines, jail sentences or lawsuits. Simply following the regulatory rules will not protect the company from product liability. So, even though the manufacturer follows all regulatory rules remains extra duty to take care of the safety of the products - to have products free from errors in design, manufacture and labeling. Manufacturers should implement GMP, but they should serve only as a foundation for further work. Companies need always to strive to overcome and improve all regulatory requirements (Quinley, 2007).

\section{Manufacturers should not make confusion between risk management and purchase of liability insurance}

Possession of liability insurance is part of the risk management process. But, good risk management must go beyond purchasing insurance. Some organizations try to delegate the risk management by purchasing premium insurance. They believe that this way they will resolve the risk, but acctualy they are actting short sighted. Although the purpose of the liability insurance is to recover the losses they had, the company rarely achieves it. Insurance almost always fails to regain the lost business opportunities, reputation, users/patients, staff morale, etc. In fact there is no such insurance that could bear all these costs. Hence, insurance only provides a false sense of security. For this reason, manufacturers need better risk management and they should use liability insurance only as a protection from genuine catastrophic losses (Quinley, 2007).

\section{Conclusion}

From the overall analysis, it can be concluded that the medical device risk management process is not an instantaneous or one-time project. It is an ongoing process, constantly reviewed and assessed over the medical device life-time. Manufacturing companies with serious approach to the process, face fewer defects, as well as increased patient safety.

By reviewing the implementation of safety and quality standards and also the risk management system, greater confidence in the use of the medical device is provided. The introduction of traceability and identification systems also promotes their safety and quality.

But, reacently it was observed that a growing number of patients/users experience adverse effects arising from the medical device use. Surveys showed the existence of systemic gaps in the quality assurance process within the medical device industry.

The 'root cause' analysis revealed that the main reason for more than the half of the market recalls are triggered by failures in product design and process control during production itself, and not, as it was often thought, in the range of the therapeutic area.

The quality economy changed significantly. In the past, when the products were put on market in the early stages of development, it meant that their use is much more profitable than the costs incurred as a result of the absence of a high level quality and reliability.

The risk-benefit analysis is out of great importance since it searves as a warning to the manufacturers about possible risk/benefit issues during device usage. Also it contributes to the completion of the product liability.

The manufacturer is required to promote the postproduction duty to warn, because some hidden risks become visible after the medical device distribution. Postproduction duty to warn also includes the duty to monitor the changes in technology and post-production monitoring of risks.

Furthermore, through practical examples of the ways manufacturers overcome the potential risks to protect their users/patients, some suggestions were given how the manufacturers should learn through personal and competitiors experience.

Finally, it was concluded that the best time to implement the risk management methods and analysis, ranging from the development and design of the device through the production, sales and distribution, in order manufacturers to protect their users/patients of serious side effects and also protect its brand and status in the society while minimizing their economic losses, is the early stage of the medical device design and development.

\section{References}

Dumbrique, R., 2010. Implementation of risk management in the medical device industry. SJSU Scholar Works. San Jose State University, http://scholarworks.sjsu.edu/gen_eng $\mathrm{grad} /$. (Accessed 15 May 2013).

FDA, 2011. Understanding barriers to Medical Device Quality, http://www.fda.gov/downloads/AboutFDA/CentersOffices/ CDRH/CDRHReports/UCM277323.pdf. (Accessed 12 February 2012)

http://www.ptc.com/W CMS/files/141876/en/ RiskManagementMedDevStudyReporFinal.pdf. (Accessed 8 February 2012).

Praveen, S.M., 2012. http://www.slideshare.net/FrostandSullivan/ european-medical-devices-industry-assessment-asymptomatic-evaluation. (Accessed 20 February 2013).

Quinley, K., 2007. Best Practices in product liability Risk Management, MPO Articles. http//www.mpo-mag.com/ 
articles/2007/03/best-practices-in-product-liability-riskmanagemen. (Accessed 5 October 2012).

Reportlinker, 2014. Medical Device Indystry: Market research reports, statistics and analysis www.report linker.com/ Medical-Devices.html. (Accessed 5 April 2013).
WebFinance, 2014. Definition of risk, http://www. businessdictionary.com/definition/risk.html. (Accessed 2 February 2013).

Zimmermann, M., 2008. European Union Medical Device Regulations Summary Report on Guiding Principles, Progeritas.

\title{
Резиме
}

\section{Управување со ризик кај медицински помагала и неговото економско влијание}

\author{
Катерина Крстева Јакимовска ${ }^{1 *}$, Марија Главаш-Додов², Јасмина Тониќ-Рибарска², \\ Сузана Трајковиќ-Јолевска \\ ${ }^{1}$ Промеоика ДООЕЛ, Скойје, Макеоонија

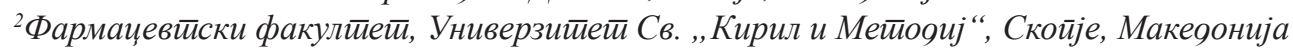

Клучни зборови: Медицинско помагало, управување со ризик, несакани ефекти, пазар на медицински помагала, ризик-корист.

Медицинските помагала имаат огромно значење во секојдневниот живот на корисниците/пациентите. Тоа е основната причина поради која посебно значење се дава на безбедноста при нивната употреба. Задоволително ниво на безбедност при употребата на медицинските помагала може да се постигне со имплементација на стандардите за квалитет и управување со ризик. Производителите на медицински помагала мораат да научат да се справуваат со појавата на потенцијални ризици преку користење на теоретски и практични примери и мерки, а сето тоа да го направат со една единствена цел, да ги заштитат потенцијалните корисници/пациенти, како и себе,од огромни загуби кои би можеле да се појават како резултат на несакани ефекти или отповикувања на нивните производи. Најдобар момент за имплементација на методите и анализите за управување со ризик започнува од моментот на дизајн и развој на медицинското помагало, преку производството, продажбата и дистрибуцијата. На овој начин, производителите на медицински помагала ќе успеат да ги заштитат своите корисници/пациенти од сериозни несакани ефекти и истовремено да го заштитат својот бренд и општествен статус, притоа намалувајќи ги потенцијалните економски загуби. 
